\title{
Farmers Adaptation Strategies to Climate Change in Obowo Local Government Area of Imo State, Nigeria
}

\author{
${ }^{1}$ Onoh, P.A., ${ }^{1}$ Ugwoke, F. O., ${ }^{1}$ Echetama, J.A., ${ }^{1}$ Ukpongson, M. A., ${ }^{1}$ Agomuo, \\ C.I., ${ }^{1}$ Onoh, A. L. and ${ }^{2}$ Ewelu, I. A. \\ ${ }^{1}$ Department of Agricultural Extension, Federal University of Technology Owerri, Nigeria \\ Dept. of Agric. Extension, University of Nigeria, Nsukka, Nigeria.
}

\begin{abstract}
The study examined farmers' adaptation strategies to climate change in Obowo Local Government Area of Imo state, Nigeria. The specific objectives of the study were to determine the socio-economic characteristics of the farmers in the area, ascertain the level of awareness of farmers on the effects of climate change, and assess the adaptation strategies of different farming systems to climate change. Validated and well structured questionnaire were used to collect data from sixty randomly selected farmers. Data analysis was done using simple and inferential statistical tools such as frequency counts, mean, and ordinary least square multiple regression. The study showed that majority of the farmers were males (60\%) with a mean annual income of N155844.58 and mean age of 47.16 years. Their major source of information on climate change was from friends/neighbours (informal sources) (mean $=2.70$ ) and very few (mean $=0.92$ ) sourced information from the print media (newspaper). Their major idea of climate change was excessive rainfall. Their major adaptation strategies in the area were by the use of mixed cropping (Mean $=2.75)$, mulching (mean = 2.50 ) and cover crops (mean $=2.60$ ). Only very few of them adopted minimum tillage and practiced afforestation as a measure with very low mean adaptation of 0.10 and 0.50 respectively. None of them practiced irrigation farming. The factors influencing farmers' adaptation to climate change included level of education, farm size, farm income and age. The study showed that age has an inverse relationship to climate change adaptation. It was therefore recommended that agricultural extension workers should increase their level of service on the use of afforestation as a mitigation measure on climate change.
\end{abstract}

Key words: Farmers, Strategy, Climate Change, Adaptation, Nigeria

\section{Introduction}

Agricultural activity is highly sensitive to climate change, largely because it depends on biodiversity and environmental conditions. As agriculture depends directly on environmental conditions, climate change impacts on agriculture are becoming increasingly evident. Small scale farmers are among the first to feel the impact of climate change because of their greater dependence on the environment [1]. Extreme climate variability (drought and flood) can destroy the economies and welfare of poor rural families because they lack technologies, social protection mechanism and adequate protection for their crops and animals. Effective climate change predictions will have far reaching impact on adaptation decisions. However, [2] , maintained that it is no longer possible to predict future climate characteristics using historical events. Poor and remote communities are especially vulnerable to climate change as they tend to be unable (or less able) to access relevant information on possible changes in climate, or warnings of unpredictable weather events. Such communities have tended to rely on traditional indicators of climate and weather patterns such as the appearance of migratory birds or the flowering of certain trees. As both weather patterns and the traditional indicators become unreliable, farmers are highly vulnerable to production losses which might result from unpredictable weather events [3] .

Studies indicate that Africa's agriculture is negatively affected by climate change. [4] stated that adaptation is one of the policy options for reducing the negative impact of climate change. Adaptation refers to adjustment in natural and human systems in response to actual or expected opportunities [5]. Common adaptation methods in agriculture include use of high yielding crop varieties and livestock species, irrigation, crop diversification, adoption of mixed crop farming systems, and changing planting dates. [6] showed that there are several ways to adapt to climate change at the farm level. Those different ways they stated were complimentary as they addressed different components of the small holder farming system. Adaptation was confirmed to be a continuum of practices which ranges from activities that are predominantly developmental to those that focus on reducing climate change impacts. They maintained that no one single measure was sufficient to adapt to climate change, rather a mix of measures is needed which targets the various farm variables - water, soil, micro-climate, seeds and crops as well as labour and capital. Hence this study seeks to determine farmers' adaptation strategies to climate change in Obowo Local Government Area of Imo State. The specific objectives of the study include to:

1. determine the socio-economic characteristics of the farmers in the area; 
2. ascertain the level of awareness of farmers on the effects of climate change; and

3. assess the adaptation strategies of different farming systems to climate change.

\section{Methodology}

The study was conducted in Obowo Local Government Area of Imo State Nigeria.Obowo is made up of fourteen communities namely: Amuzi, Alike ,Umuariam ,Achara ,Avutu ,Ehume ,Umusochie, Okwuochia, Odenkwume, Umugwa, Umulogho, Umuokeh, Umunachi and Amanse. It has a total population of 64,000 people and occupies a total land area of $46,053 \mathrm{~km}^{2}$ [7]. It lies within latitude $4^{0} 45^{1}$ and $7^{0} 15^{1}$ north of the equator and longitude $6^{0} 50^{1}$ and $7^{0} 25^{1}$ East of the Meridian. The study area experiences two major climatic seasons: the rainy season (which last between March and October) and a four month dry season (usually between November and February). The people are Igbos and share similar socio-cultural characteristics with most Igbo communities in Nigeria .Their major economic activities include farming, trading, food processing and craft making

The sampling employed was multi-stage sampling technique. Six communities were randomly selected for the study .These communities included; Umuariam, Avutu, Alike, Umuoke, Umulogho and Achara .Ten farmers were randomly selected from each of the six communities to give a total of sixty farmers interviewed for the study. The data used were collected from two main sources, primary and secondary sources . The primary data were collected using structured questionnaire, while the secondary data were obtained from the publication of relevant agencies like Ministry of Agriculture, text books, journals and conference proceedings, etc .To describe the sources of information, farmers awareness and adaptation in mitigating the effects of climate change, respondents were asked to identify from listed items the measure of importance. A 4- point Likert -type scale was used. The values on the scale were added and divided by 4 to get a mean value of 2.5 . Any value with mean score greater than or equal to 2.5 was considered important, while values of less than 2.5 were not considered important. Descriptive and inferential statistical tools were also used in the analysis. They included percentages ,frequency distribution and means while ordinary least square regression analysis was used to test the hypothesized relationship which states that "there is no significant relationship between the socio-economic characteristics and farmers "adaptability to climate change". Four functional forms of the ordinary least square multiple regression model were tried and the best fit was selected based on the number of significant variables, coefficient of multiple determination $\left(\mathrm{R}^{2}\right)$ and the $\mathrm{F}$-value. The model is specified as follows:

$\mathrm{Y}=\mathrm{f}\left(\mathrm{X}_{1}, \mathrm{X}_{2}, \mathrm{X}_{3}, \mathrm{X}_{4}, \mathrm{X}_{5}, \mathrm{X}_{6}, \mathrm{e}\right)$

Where:

$\mathrm{Y}=$ Farmers' adaptation to climate change $($ High adaptation $=3$, Moderate adaptation $=2$, Low adaptation $=1$ )

$\mathrm{X}_{1}=$ Farming experience (in years)

$\mathrm{X}_{2}=$ Farm income (in naira)

$\mathrm{X}_{3}=$ Age of the farmers ( in years)

$\mathrm{X}_{4}=$ Educational level (number of years spent in school)

$\mathrm{X}_{5}=$ Occupation (farming $=1$, non-farming $=0$ )

$\mathrm{X}_{6}=$ Household size (the number of persons per household)

$\mathrm{e}=$ error term

\section{Socio-economic characteristics}

\section{Results and Discussion}

The socio-economic characteristics of farmers such as age, gender, education, marital status, household size, farming experience and annual income were analyzed and presented in table 1 . The results indicated that majority ( $60 \%$ ) of the farmers were males ,most of whom were married (86.67\%). Another majority $(33.33 \%)$ fell within the ages of 41-50 years. The mean age was 47.16 years, while $55 \%$ of them had annual income of between N100, 001.00 - N200, 000.00. About 42\% of them spent $1-6$ years in school and 53.33\% had 16-20 years of farming experience. The mean household size, years of farming experience, annual income and years spent in school were 7, 18.1 years, N155, 844.58 and 5.93 years respectively. This implies that the farmers were mostly of active age, low income, and with very little formal education. This result is in agreement with the findings of other studies on socio-economic characteristics of rural dwellers in Nigeria [8] and [9].

\section{Sources of information to the farmers}

The results on sources of information on on climate change showed that the major sources of information on climate change were from friends/neighbours (Mean $=2.70)$, fellow farmers $($ Mean $=2.50)$, radio (Mean $=2.65)$, television (Mean $=2.0$ ), farmers' cooperatives (Mean $=1.75$ ) and extension workers $($ Mean $=1.70)$. The least source was from the print media (Mean $=0.65)$. This could be explained by the low level of education prevalent in Nigeria's rural area [10]. 
Awareness of the effects of climate change

Table 3 shows that farmers were aware that excessive rainfall (Mean $=2.60)$, change in rainfall pattern $($ Mean $=2.53)$, soil erosion $($ Mean $=2.55)$ and flooding $($ Mean $=2.00)$ were the signs of climate change in the area. They however did not see increase in temperature (Mean $=0.75)$ and rise in sea level $($ Mean $=1.05)$ as signs of climate change. [11] stated that rainfall is by far the most important element of climate change in Nigeria. He said that heavy rainfalls with resultant floods are frequent in areas hitherto known to have optimum rains.

\section{Adaptation strategies in mitigating the effects of climate change}

Results in table 4 showed the strategies adapted by farmers in mitigating the effects of climate change. The major strategies included, mixed cropping (Mean $=2.75)$, mulching (Mean $=2.50$ ), use of cover crops (Mean $=2.60)$ and bush fallowing $(2.52)$. Other measures, though not significant included crop rotation (Mean $=1.75$ ), and use of organic matter (Mean $=1.50$ ). However, irrigation and afforestation were not commonly used by the farmers [12]. stated that important adaptation strategies included amongst others ;adoption of soil conservation techniques ( Cover cropping, mulching , application of fertilizer.)

\section{Regression estimates of the determinants of farmers' adaptation to climate change}

Table 5 shows that the exponential model provided the best fit and was thus used in describing the relationship. The F-value was 18.1873 and the number of significant variables was five, the coefficient of multiple determination $\left(\mathrm{R}^{2}\right)$ was 0.7428 . This result implies that about 74 percent of the variations in the adaptation strategies to climate change by the farmers were brought about by the combined effects of the socioeconomic variables investigated. The coefficient of educational level $(\mathrm{t}=3.4961, \mathrm{p}<0.05)$, age $(\mathrm{t}=-3.2231$, $\mathrm{p}<0.01)$, farm size $(\mathrm{t}=3.0916, \mathrm{p}<0.05)$, farm income $(3.2350, \mathrm{p}<0.05)$, and farming experience $(3.3839, \mathrm{p}<0.05)$ were significant, implying that these variables were important factors influencing the adaptation strategies to climate change in the study area. The result also showed that the more educated the farmers are, the more they are likely to adjust to climate change in order to moderate potential damages. It also implied that education would position them to take advantage of new techniques and innovations that mitigate the effects of climate change and boost food security. Age has negative relationship with adaptation, implying that increase in age reduces farmers' adaptation to climate change. Younger farmers are more adaptable to changes.

\section{Conclusion and Recommendations}

The farmers' major idea of climate change was excessive rainfall while adaptation strategies practiced were mulching and the use of cover crops .A negligible few adapted minimum tillage and afforestation as a measure .Age had an inverse relationship to climate change adaptation. It was recommended that Agricultural Extension Service should increase their level of service on the use of afforestation as an adaptation measure to climate change.

Table 1: Distribution of the respondents based on socio-economic characteristics $(\mathrm{N}=60)$

\begin{tabular}{|c|c|c|c|}
\hline Variable & Frequency & Percentages (\%) & Mean \\
\hline \multicolumn{4}{|c|}{ Age(years) } \\
\hline $21-30$ & 3 & 5.00 & \\
\hline $31-40$ & 13 & 21.67 & \\
\hline $41-50$ & 20 & 33.33 & \\
\hline $51-60$ & 13 & 21.67 & 47.16years \\
\hline$>60$ & 11 & 18.33 & \\
\hline Total & 60 & 100.00 & \\
\hline \multicolumn{4}{|l|}{ Gender } \\
\hline Male & 36 & 60.00 & \\
\hline Female & 24 & 40 & \\
\hline Total & 60 & 100.00 & \\
\hline \multicolumn{4}{|c|}{ Marital Status } \\
\hline Married & 52 & 86.67 & \\
\hline Single & 5 & 8.33 & \\
\hline Divorced & 2 & 3.33 & \\
\hline Widowed & 1 & 1.67 & \\
\hline Total & 60 & 100.00 & \\
\hline \multicolumn{4}{|c|}{ Household Size } \\
\hline $1-3$ & 6 & 10.00 & \\
\hline $4-6$ & 17 & 28.33 & \\
\hline $7-9$ & 24 & 40.00 & \\
\hline $10-12$ & 13 & 21.67 & 7.2 people \\
\hline Total & 60 & 100.00 & \\
\hline \multicolumn{4}{|c|}{ Years of farming } \\
\hline$<10$ & 4 & 6.67 & \\
\hline $11-15$ & 10 & 16.67 & \\
\hline
\end{tabular}


Farmers Adaptation Strategies to Climate Change in Obowo Local Government Area of Imo State,

\begin{tabular}{llll}
\hline $16-20$ & 32 & 53.33 & 18.1 years \\
$21-25$ & 8 & 13.33 & \\
26 and above & 6 & 10.00 & \\
Total & $\mathbf{6 0}$ & $\mathbf{1 0 0 . 0 0}$ & \\
Annual Income (N) & 13 & 21.67 & N $155,844.58$ \\
$1000-100,000.00$ & 33 & 55.00 & \\
$100,001-200,000.00$ & 9 & 15.00 & \\
$200,001.00-300,000.00$ & 5 & 8.33 & \\
Above $300,000.00$ & $\mathbf{6 0}$ & $\mathbf{1 0 0 . 0 0}$ & \\
Total & 9 & 15.0 & 5.93 years \\
Years of formal education & 25 & 41.67 & \\
No formal education & 20 & 33.33 & \\
$1-6$ & 6 & 10.00 & \\
$7-12$ & $\mathbf{6 0}$ & $\mathbf{1 0 0 . 0 0}$ & \\
Above 13 & & & \\
Total & &
\end{tabular}

Source: Field survey, 2013

Table 2: Distribution of respondents according to sources of information on climate change.

\begin{tabular}{lll}
\hline Sources & Mean $(\mathbf{M})$ & STD. Deviation \\
\hline Friends/neighbours & $2.70^{*}$ & 0.86 \\
Extension Workers & 1.70 & 1.20 \\
Farmers Cooperatives & 1.75 & 1.06 \\
News Papers & 0.65 & 0.92 \\
Radio & $2.65^{*}$ & 1.15 \\
Fellow Farmers & $2.50^{*}$ & 0.82 \\
Television & 2.00 & 0.88 \\
\hline
\end{tabular}

Source: Field survey, 2013

Table 3: Distribution of respondents based on awareness of climate change effects

\begin{tabular}{lll}
\hline Effects of Climate Change & Mean $(\mathbf{M})$ & STD Deviation \\
\hline Excessive Rainfall & $2.60^{*}$ & 0.86 \\
Flooding & 2.00 & 1.01 \\
Soil Erosion & $2.55^{*}$ & 0.89 \\
Increase in Pests and Disease & 1.55 & 1.20 \\
Rise in Sea level & 1.05 & 1.22 \\
Change in Rainfall Pattern & $2.53^{*}$ & 1.25 \\
High wind and Heat Waves & 1.75 & 0.99 \\
Crop Failure & 1.50 & 1.09 \\
Increased Temperature & 0.75 & 1.26 \\
\hline
\end{tabular}

Source: Field survey, 2013

Table 4: Adaptation strategies for Mitigating the effects of climate change

\begin{tabular}{lll}
\hline Adaptation Measures & Mean $(\mathbf{M})$ & STD Deviation \\
\hline Use of Organic Matter & 1.5 & 1.22 \\
Use of pest and disease resistant crops & 0.75 & 1.21 \\
Mulching & $2.50^{*}$ & 0.98 \\
Planting of trees & 0.50 & 1.40 \\
Increased Use of Fertilizer & 1.00 & 1.20 \\
Use of herbicides and insecticides & 0.40 & 0.96 \\
Change in Planting Date & 0.90 & 1.23 \\
Mixed Cropping Practices & $2.75^{*}$ & 1.25 \\
Cover Cropping & $2.60^{*}$ & 0.97 \\
Crop rotation & 1.75 & 1.21 \\
Use of early maturing Varieties & 0.25 & 0.98 \\
Use of Minimum Tillage System & 0.10 & 1.23 \\
Irrigation Practices & 0.02 & 0.96 \\
Fallowing & $2.52^{*}$ & 1.15 \\
\hline
\end{tabular}

Source: Field survey, 2013

Table 5: Analysis of the determinants to farmers' adaptation to climate change

\begin{tabular}{lllll}
\hline Explanatory variable & Linear function & $\begin{array}{l}\text { Semi-log } \\
\text { Function }\end{array}$ & Exponential function & Double-log \\
\hline Constant & 13.9210 & 24.1831 & 6.9076 & 4.7897 \\
X $_{1}$ (Experience) & 0.3299 & 0.7144 & 0.0089 & 0.657 \\
& $(1.1277)$ & $(3.4999)^{* *}$ & $(3.3839)^{* *}$ & $(2.8979)^{* *}$ \\
X $_{2}$ (Farm Income) & 0.73209 & 0.5054 & 0.0091 & 0.0819 \\
& $(3.6071)$ & $(3.0494)^{* *}$ & $(3.2350)^{* *}$ & $(3.2497)^{* *}$ \\
$X_{3}$ (Age) & -1.9103 & -0.1167 & -0.0082 & -0.0361 \\
& $(-1.1699)$ & $(-1.1671)^{*}$ & $(-3.2231)^{* *}$ & $(-1.2294)$
\end{tabular}


Farmers Adaptation Strategies to Climate Change in Obowo Local Government Area of Imo State,

\begin{tabular}{lllll}
\hline & & & & \\
\hline $\mathrm{X}_{4}$ (educational level) & 1.0371 & 1.8465 & 0.0081 & 0.0739 \\
& $(1.1239)$ & $(1.2671)$ & $(3.4961)^{* *}$ & $(1.2316)$ \\
$\mathrm{X}_{5}$ (occupation) & 0.3394 & 0.9216 & 0.0073 & 0.0791 \\
& $(2.1696)^{*}$ & $(1.3225)$ & $(1.0978)$ & $(3.7913)$ \\
$\mathrm{X}_{6}$ (Household size) & 0.0321 & -0.6106 & -0.0069 & $(-3.3398)^{* *}$ \\
$\mathrm{R}^{2}$ & $(2.7294)^{*}$ & $(-1.2039)$ & $(-2.4391)^{*}$ & 0.6119 \\
$\mathrm{f}$ - value & 0.5148 & 0.4038 & 0.7428 & $9.1967 * *$ \\
Number of variables & $6.7586^{* *}$ & $4.1204 * *$ & $18.1873 * * *$ & 6 \\
Number of observations & 6 & 6 & 6 & 60 \\
\hline
\end{tabular}

Source: Field survey, $2013 \quad$ Lead equation = Exponential function

$*=$ Significant at $\mathrm{p}<0.10, * *=$ Significant at $\mathrm{P}<0.05, * * *=$ Significant at $\mathrm{P}<0.01$

Figures in parenthesis are t-ratios

\section{Reference}

[1]. Onumadu, F. N. (2010). Agro forestry Extension. As an Effective Tool for Mitigating Climate Change in Nigeria. In: S. K. Adeyoju and S. O. Bada (eds.) Readings in Sustainable Tropical Forest Management: Essays in Honour of Professor Labode Popoola .Zenith book House 3, Lydia Close, Ashi, Bodija Pp 53-75

[2]. Popoola, L .(2010). Understanding Climate Change .Context, Drivers and Impacts .Tribune News paper .Saturday, June 5 ,2010 . Fraser, E. (2008). Impact of Climate Change on Agriculture. Retrieved on March 20, 2013, from www.wikipedia.org /wiki/climate/change

[3]. Fraser, E. (2008). Impact of Climate Change on Agriculture. Retrieved on March 20, 2013, from www.wikipedia.org /wiki/climate/change.

[4]. Oladipo, E. (2010). Towards Enhancing the Adaptive Capacity of Nigeria: A Review of the Country's 'state of Preparedness for Climate Change Adaptation. Report submitted to Heinrich Boll Foundation, Nigeria

[5]. FAO (2010). Climate - Smart Agriculture, Policy, Practices and Financing for Food Security, Adaptation and Mitigation, FAO, Rome

[6]. Ensor J. and R.Berger (2009). Understanding Climate Change Adaptation: Lessons from Community-Based Approaches, Practical Action Publishing, Rugby, U. K.

[7]. National Population Commission (NPC) (2006). National Census Figures. NPC, Abuja, Nigeria.

[8]. Asiabaka C. C.(2002). Agricultural Extension: A handbook for Development Practitioners,, Molsyfem United Services, Ahoada, Rivers State, Nigeria.

[9]. Nnadi , F .N .and Amaechi, E .C.C.I. (2004). Rural Sociology for Development Studies . Custodab Investment, Owerri, Nigeria

[10]. Asiabaka,C. C.(2010). Scaling up Agricultural Technologies for Food Security and Poverty Reduction: Whose Knowledge Counts The Farmer or The Scientist? $16^{\text {th }}$ Inaugural Lecture of the Federal University of Technology Owerri (FUTO), Imo State, Nigeria

[11]. Adejuwon, S. A.( 2004 ). Impact of Climate Variability and Climate Change on Crop yield in Nigeria contributed paper to stakeholders workshop on Assessment of Impact and Adaptation to Climate Change (AIACC).282,2-8

[12]. Onyeneke,R.U. and Madukwe ,D.K.(2010). Adaptation Measures by crop Farmers in the Southeast Rainforest zone of Nigeria to Climate Change, Science World journal 5(1):49-54 